\title{
PENGARUH KECERDASAN INTELEKTUAL, EMOSIONAL DAN SPIRITUAL TERHADAP PRESTASI BELAJAR PENDIDIKAN KEWARGANEGARAAN
}

\author{
Heri Kurnia \\ Pendidikan Pancasila dan Kewarganegaraan, Universitas Cokroaminoto Yogyakarta \\ Jl. Perintis Kemerdekaan, Gambiran, Umbulharjo, Kota Yogykarta 55161 \\ Email: herikurnia@ucy.ac.id
}

\begin{abstract}
ABSTRAK
Penelitian ini bertujuan untuk mengetahui: 1). pengaruh kecerdasan intelektual terhadap prestasi belajar Pendidikan Kewarganegaraan, 2). pengaruh kecerdasan emosional terhadap prestasi belajar Pendidikan Kewarganegaraan, 3). pengaruh kecerdasan spiritual terhadap prestasi belajar Pendidikan Kewarganegaraan dan 4). pengaruh kecerdasan intelektual, emosional dan spiritual secara simultan terhadap prestasi belajar Pendidikan Kewarganegaraan.

Populasi penelitian ini adalah seluruh siswa Sekolah Menengah Atas Negeri di Kota Yogyakarta tahun ajaran 2016/2017 yang terdiri atas 11 Sekolah Menengah Atas Negeri dengan jumlah 8.073 siswa. Penentuan sampel dilakukan dengan teknik simple random sampling atau acak sederhana. Dari 11 Sekolah Menengah Atas Negeri di Kota Yogyakarta diambil sampel 367 siswa, dengan ketentuan setiap Sekolah Menengah Atas Negeri terkait yang dijadikan sampel adalah siswa kelas $\mathrm{X}$ dan siswa kelas XI. Data kecerdasan intelektual dan prestasi belajar Pendidikan Kewarganegaraan diperoleh dari dokumen, data kecerdasan emosional dan kecerdasan spiritual diperoleh melalui penyebaran kuesioner. Teknik analisis data yang digunakan untuk menguji hipotesis adalah regresi sederhana dan regresi linier berganda.

Hasil penelitian disimpulkan 1). terdapat pengaruh positif dan signifikan kecerdasan intelektual terhadap prestasi belajar Pendidikan Kewarganegaraan, dengan sig. (P) sebesar 0,000 $<0,05$ persamaan regresi sebesar 0,119. 2). Terdapat pengaruh positif tapi tidak signifikan kecerdasan emosional terhadap prestasi belajar Pendidikan Kewarganegaraan, dengan sig. (P) sebesar 0,119>0,05 persamaan regresi sebesar -0,064. 3). Terdapat pengaruh positif tapi tidak signifikan kecerdasan spiritual terhadap prestasi belajar Pendidikan Kewarganegaraan, dengan sig. (P) sebesar 0,365 > 0,05 persamaan regresi sebesar 0,040.4). Terdapat pengaruh positif dan signifikan kecerdasan intelektual, emosional dan spiritual terhadap prestasi belajar Pendidikan Kewarganegaraan, dengan sig. (P) sebesar $0,000<0,05$. Besarnya koefisien determinasi (adjusted $R^{2}$ ) $=0,051$ artinya variabel bebas secara simultan mempengaruhi variabel terikat sebesar $5,1 \%$ sisanya sebesar $94.9 \%$ dipengaruhi oleh variabel yang tidak dimasukan dalam penelitian ini.
\end{abstract}

Kata Kunci: Kecerdasan intelektual, kecerdasan emosional, kecerdasan spiritual dan prestasi belajar Pendidikan Kewarganegaraan 


\begin{abstract}
This study aims to find out: 1). the effect of intellectual intelligence on learning achievement in Civic Education, 2). the effect of emotional intelligence on learning achievements in Civic Education, 3). the influence of spiritual intelligence on learning achievements in Civic Education and 4). the effect of simultaneous intellectual, emotional and spiritual intelligence on the learning achievement of Citizenship Education.

The population of this study was all students of State Senior High Schools in the City of Yogyakarta 2016/2017 academic year consisting of 11 State Senior High Schools with a total of 8073 students. Determination of the sample is done by simple random sampling technique. Of the 11 Public High Schools in the City of Yogyakarta, 367 students were sampled, with the provisions that each associated State High School sampled were class X students and class XI students. Data on intellectual intelligence and learning achievements in Civic Education were obtained from documents, data on emotional intelligence and spiritual intelligence were obtained through questionnaires. Data analysis techniques used to test hypotheses are simple regression and multiple linear regression.

The results of the study were concluded 1). there is a positive and significant influence of intellectual intelligence on the learning achievement of Citizenship Education, with sig. (P) equal to $0,000<0.05$ regression equation of 0.119 .2 ). There is a positive but insignificant influence of emotional intelligence on the learning achievement of Citizenship Education, with sig. (P) of $0.119>0.05$ regression equation of -0.064 . 3). There is a positive but insignificant influence of spiritual intelligence on the learning achievement of Citizenship Education, with sig. (P) of $0.365>0.05$ regression equations of 0.040 . 4). There is a positive and significant influence of intellectual, emotional and spiritual intelligence on the learning achievement of Citizenship Education, with sig. (P) $0,000<0.05$. The magnitude of the coefficient of determination (adjusted $R 2)=0.051$ means simultaneously independent variables affect the dependent variable of $5.1 \%$ for the remaining $94.9 \%$ is influenced by variables that are not included in this study.
\end{abstract}

Keywords: Intellectual intelligence, emotional intelligence, spiritual intelligence and learning achievement Citizenship Education

\title{
PENDAHULUAN
}

Hakekat pendidikan pada dasarnya merupakan suatu yang dilakukan oleh manusia untuk meningkatkan taraf hidup kearah yang lebih baik. Pendidikan merupakan suatu kekuatan dinamis yang sangat berpengaruh terhadap perkembangan fisik, mental, etika dan seluruh aspek kehidupan manusia. Fungsi Pendidikan Nasional ialah untuk mengembangkan kemampuan dan membentuk watak serta peradaban bangsa yang bermartabat dalam rangka mencerdaskan kehidupan bangsa yang bertujuan untuk berkembangnya potensi peserta didik agar menjadi manusia yang beriman dan bertaqwa kepada Tuhan Yang Maha Esa, berakhlak mulia, sehat, berilmu, cakap, kreatif, mandiri dan menjadi warga Negara yang demokratis serta bertanggungjawab (Pasal 3 Undang-Undang No 20 Tahun 2003 Tentang Sistem Pendidikan Nasional). Lembaga Pendidikan dan Tenaga Kependidikan (LPTK) khususnya Pendidikan 
Kewarganegaraan (PKn) dituntut untuk menghasilkan lulusan yang memiliki kemampuan dalam pemahaman ilmu mata pelajaran Pendidikan Kewarganegaraan (Suntoro Fauzi dan Nurmalisa, 2012).Dengan berkembangnya teknologi seperti komputer dan internet sangat memudahkan siswa untuk mengembangkan ilmu pengetahuan, walaupun demikian, teknologi yang semakin berkembang tersebut belum dapat dijadikan jaminan bagi dunia pendidikan untuk mencapai hasil yang maksimal. Salah satu faktor yang dapat mendukung keberhasilan proses pembelajaran disetiap sekolah adalah sikap dan mental dari siswa itu sendiri, terutama dalam mengembangkan kepribadiannya yang semakin dituntut untuk memiliki kemampuan dalam pemahaman ilmu Pendidikan Kewarganegaraan, sehingga hal tersebut dapat dijadikan nilai tambah (value added) kehidupan bermasyarakat dan berwarganegara.

Kurang berhasilnya pendidikan disebabkan karena sistem konvensional, yaitu suatu sistem yang lebih menekankan pada aspek kognisi, apabila siswa tersebut memiliki nilai tinggi di sekolah, maka siswa tersebut dianggap siswa yang pintar, cerdas dan berkualitas. Untuk dapat menghasilkan lulusan yang berkualitas, maka sekolah harus terus meningkatkan kualitas pada sistem pendidikannya dan tidak hanya berorientasi terhadap nilai kognisi. Beberapa sekolah belum mampu mengantarkan anak didiknya menguasai pengetahuan dan keterampilan hidup dengan baik. Siswa terbiasa dengan pola belajar menghafal tetapi tidak memahami pelajaran tersebut. Sehingga siswa akan cenderung mudah lupa dengan apa yang pernah dipelajari atau kesulitan untuk memahami apa yang diajarkan selanjutnya. Ary Ginanjar Agustian (2005: 23), mengemukakan: "Kebanyakkan program pendidikan berpusat pada kecerdasan intelektual. Kecerdasan intelektual ini diukur dari nilai rapor dan indeks prestasi. Nilai rapor yang baik, indeks prestasi yang tinggi, atau sering juara kelas merupakan tolak ukur dari kesuksesan seseorang. Tolak ukur ini tidak salah tetapi tidak seratus persen bisa dibenarkan. Terdapat faktor lain yang menyebabkan seseorang menjadi sukses yaitu adanya kecerdasan emosional dan kecerdasan spiritual".

Hasil penelitian Goleman (2005) dan beberapa Riset di Amerika memperlihatkan bahwa kecerdasan intelektual hanya memberi kontribusi 20 persen (20\%) terhadap kesuksesan hidup seseorang. Sisanya, 80 persen $(80 \%)$ bergantung pada kecerdasan emosi, kecerdasan sosial dan kecerdasan spiritualnya. Bahkan dalam hal keberhasilan kerja, kecerdasan intelektual hanya berkontribusi 4 persen (4\%). Hasil serupa juga disimpulkan dari penelitian jangka panjang terhadap 95 siswa Hardvard lulusan tahun 1940-an. Puluhan tahun kemudian, mereka yang saat 
kuliah dulu mempunyai kecerdasan intelektual tinggi, namun egois dan pergaulannya kurang luas, ternyata hidupnya tidak terlalu sukses (berdasar gaji, produktivitas, serta status bidang pekerjaan), dibandingkan dengan orang yang kecerdasan intelektualnya biasa saja tetapi mempunyai banyak teman, pandai berkomunikasi, mempunyai empati, tidak temperamental sebagai manifestasi dari tingginya kecerdasan emosi, sosial dan spiritual (dalam Rachmi, 2010).

Kebanyakan program pendidikan hanya berpusat pada kecerdasan akal (IQ) saja yaitu berorientasi untuk menghasilkan nilai akademik, padahal yang diperlukan sebenarnya adalah bagaimana mengembangkan kecerdasan hati seperti pengenalan diri, pengendalian diri dan motivasi. Banyak contoh di sekitar kita membuktikan bahwa orang yang memiliki kecerdasan intelektual saja tetapi tidak memiliki kecerdasan emosional, belum tentu sukses di dunia pekerjaan tetapi terpuruk di tengah persaingan. Sebaliknya banyak orang yang hanya berpendidikan formal lebih rendah ternyata banyak yang lebih berhasil karena diimbangi dengan kecerdasan emosional yang baik dan tinggi. Kecerdasan emosional siswa memiliki pengaruh terhadap prestasi belajar siswa. Kecerdasan emosional ini mampu melatih kemampuan untuk mengelola perasaannya, kemampuan untuk memotivasi dirinya, kesanggupan untuk tegar dalam menghadapi frustasi, kesanggupan mengendalikan dorongan dan menunda kepuasan sesaat, mengatur suasana hati yang reaktif, serta mampu berempati dan bekerja sama dengan orang lain. Kecerdasan ini yang mendukung seorang siswa dalam mencapai tujuan dan cita-citanya.

Kecerdasan intelektual (IQ) dan kecerdasan emosional (EQ) itu saja belum cukup untuk menghantarkan seseorang mencapai puncak kesuksesan dalam kehidupannya. Sprititualitas siswa yang cerdas akan mampu membantu siswa dalam pemecahan permasalahan-permasalahan dalam pendidikan di sekolah. Pembelajaran yang hanya berpusat pada kecerdasan intelektual tanpa menyeimbangkan sisi spiritual akan menghasilkan generasi yang mudah putus asa, depresi, suka tawuran bahkan menggunakan obat-obat terlarang, sehingga banyak siswa yang kurang menyadari tugasnya sebagai seorang siswa akan mengakibatkan kurangnya motivasi untuk belajar dan sulit untuk berkonsentrasi, sehingga siswa akan sulit untuk memahami suatu mata pelajaran. Siswa yang hanya mengejar prestasi berupa nilai dan mengabaikan nilai spiritual, akan menghalalkan segala cara untuk mendapatkan nilai yang bagus, mereka cenderung untuk bersikap tidak jujur seperti mencontek pada saat ujian. Kecerdasan spiritual mampu mendorong siswa untuk mencapai keberhasilan dalam belajarnya karena kecerdasan spiritual merupakan dasar untuk mendorong berfungsinya secara efektif kecerdasan intelektual (IQ) dan kecerdasan 
emosional (EQ). Berdasarkan uraian di atas, peneliti tertarik untuk mengambil artikel dengan judul: "Pengaruh Kecerdasan Intelektual, Emosional dan Spiritual terhadap Prestasi Belajar Pendidikan Kewarganegaraan Siswa SMA Negeri se-Kota Yogyakarta Tahun Ajaran 2016/2017"'.

\section{METODE PENELITIAN}

Jenis penelitian ini adalah penelitian deskriptif. Penelitian desktiptif yaitu suatu penelitian yang menggambarkan situasi sebagaimana adanya. Data yang dikumpulkan berupa data kuantitatif (dalam hal ini prestasi belajar/ hasil belajar) dan data kualitatif yang dikuantifikasi (dalam hal ini adalah kecerdasan intelektual, kecerdasan emosional dan kecerdasan spiritual). Penelitian kuantitatif sering diartikan sebagai penelitian yang menggunakan angka-angka. Dalam pengertian yang lebih tepat, penelitian kuantitatif adalah penelitian yang berusaha untuk menguji hubungan dua hal (variabel) atau lebih. Metode kuantitatif adalah proses menemukan pengetahuan yang menggunakan data berupa angka sebagai alat menemukan keterangan mengenai apa yang ingin kita ketahui. Data yang diperoleh dalam penelitian ini adalah data nilai prestasi belajar Pendidikan Kewaragnegaraan (PKn) yang tercantum dalam rapor yang bersangkutan, tujuannya untuk mengetahui pengaruh kecerdasan intelektual, kecerdasan emosional dan kecerdasan spiritual terhadap prestasi belajar mata pelajaran Pendidikan Kewarganegaraan siswa SMA Negeri se-Kota Yogyakarta Tahun Ajaran 2016/ 2017. Untuk mencari pengaruh antara dua variabel yaitu variabel X (kecerdasan intelektual, kecerdasan emosional dan kecerdasan spiritual) yang merupakan variabel bebas (independent variable) dan variabel Y (prestasi belajar Pkn) yang merupakan variabel terikat (dependent variable). Pendekatan ini termasuk penelitian kuantitatif karena data yang diperoleh dalam bentuk angkaangka, kemudian dianalisis dengan menggunakan statistik. Sejalan dengan pendapat Sukardi (2010: 15) menyatakan, "Penelitian kuantitatif adalah data penelitian berupa angka-angka dan dianalisis menggunakan statistik". Penelitian ini berlokasi di Kota Yogyakarta, tepatnya SMA Negeri se-Kota Yogyakarta, dengan rentang waktu penelitian antara bulan Februari 2017 sampai dengan bulan Agustus 2017. 


\section{HASIL PENELITIAN DAN PEMBAHASAN}

Peneliti perlu menginformasikan kembali, bahwasanya yang dijadikan subjek dalam penelitian ini adalah siswa SMA Negeri Se-Kota Yogyakarta, sebanyak 11 SMA Negeri dengan jumlah populasi 8.073 siswa. Sampel yang peneliti ambil sebanyak 367 siswa, dengan ketentuan setiap sekolah yang dijadikan sampel merupakan siswa kelas X (sepuluh) dan kelas XI (sebelas). Selanjutnya skor kecerdasan intelektual (X1) peneliti ambil dari bentuk dokumen, skor kecerdasan Emosional (X2) dan kecerdasan spiritual (X3) peneliti ambil dengan menyebarkan kuesioner, sedangkan nilai prestasi belajar Pendidikan Kewarganegaraan/ PKn siswa (Y) merupakan nilai akhir pada semester gasal Tahun Ajaran 2016/2017.

Alat analisis yang digunakan peneliti adalah SPSS versi 22 for windows, berikut ini adalah hasil penelitian:

\section{Deskripsi Data}

a. Kecerdasan Intelektual

Berdasarakan analisis data dengan menggunakan bantuan pogram SPSS untuk variabel kecerdasan intelektual (IQ) diperoleh hasil mean sebesar 122,48 standar deviasi sebesar 7,208. Skor terrendah responden adalah 98 dan skor tertinggi adalah 151. Agar lebih mudah dipahami dan supaya lebih mudah dibaca, maka data tersebut ditampilkan dalam bentuk tabel sebagaimana tertera pada tabel berikut ini.

\section{Tabel 1 Distribusi Fekuensi Bergolong Kecerdasan Intelektual}

\begin{tabular}{|c|c|c|}
\hline Rentang & Frequensi & Persentase (\%) \\
\hline $96-101$ & 2 & 0.5 \\
$102-107$ & 3 & 0.8 \\
$108-113$ & 12 & 3.3 \\
$114-118$ & 56 & 15.3 \\
$119-124$ & 195 & 53.1 \\
$125-130$ & 67 & 18.3 \\
$131-136$ & 9 & 2.5 \\
$137-142$ & 15 & 4.1 \\
$143-148$ & 6 & 1.6 \\
$149-154$ & 2 & 0.5 \\
Total & $\mathbf{3 6 7}$ & $\mathbf{1 0 0 0}$ \\
\hline
\end{tabular}

Sumber: Olah data menggunakan SPSS versi 22

Tabel di atas menunjukan bahwa rentang 96-101 sebanyak 2 (0,5\%), rentang 102-107 sebanyak $3(0,8 \%)$, rentang 108-113 sebanyak 12 (3,3\%), rentang 114-118 sebanyak 56 (15,3\%), rentang 119-124 sebanyak 195 (53,1\%), rentang 125-130 sebanyak 67 (18,3\%), rentang 131-136 
sebanyak 9 (2,5\%), rentang 137-142 sebanyak 15 (4,1\%), rentang 143-148 sebanyak $6(1,6 \%)$ dan rentang 149-154 sebanyak $2(0,5 \%)$.

b. Kecerdasan Emosional

Berdasarakan analisis data dengan menggunakan bantuan pogram SPSS untuk variabel kecerdasan emosional (EQ) diperoleh hasil mean sebesar 51,25 standar deviasi sebesar 6,671. Batas skor minimal adalah 15 sedangkan batas skor maksimalnya adalah 75. Skor terrendah responden adalah 35 dan skor tertinggi adalah 75. Berukut di bawah ini:

\section{Tabel 2 Distribusi Fekuensi Bergolong Kecerdasan Emosional}

\begin{tabular}{|c|cc|}
\hline Rentang & Frequensi & Persentase $(\%)$ \\
\hline $35-38$ & 3 & 0.8 \\
$39-43$ & 40 & 10.9 \\
$44-47$ & 68 & 18.5 \\
$48-51$ & 86 & 23.4 \\
$52-55$ & 94 & 25.6 \\
$56-59$ & 30 & 8.2 \\
$60-63$ & 27 & 7.4 \\
$64-67$ & 13 & 3.5 \\
$68-71$ & 4 & 1.1 \\
$72-75$ & 2 & 0.5 \\
Total & $\mathbf{3 6 7}$ & $\mathbf{1 0 0 . 0}$ \\
\hline
\end{tabular}

Sumber: Olah data menggunakan SPSS versi 22

Tabel di atas menunjukan bahwa rentang 35-38 sebanyak 3 (0,8\%), rentang 39-43 sebanyak 40 (10,9\%), rentang 44-47 sebanyak 68 (18,5\%), rentang 48-51 sebanyak 86 (23,4\%), rentang 52-55 sebanyak 94 (25,6\%), rentang 56-59 sebanyak 30 (8,2\%), rentang 60-63 sebanyak $27(7,4 \%)$, rentang 64-67 sebanyak $13(3,5 \%)$, rentang 68-71 sebanyak $4(1,1 \%)$, dan rentang 72 75 sebanyak $2(0,5 \%)$.

c. Kecerdasan Spiritual

Berdasarakan analisis data untuk variabel kecerdasan spiritual $(S Q)$ diperoleh hasil mean sebesar 39,08 standar deviasi sebesar 6,219. Batas skor minimal adalah 12 sedangkan batas skor maksimalnya adalah 60. Skor terrendah responden adalah 24 dan skor tertinggi adalah 58. Berikut ini data Kecerdasan Spiritual: 
Tabel 3 Distribusi Fekuensi Bergolong Kecerdasan Spiritual

\begin{tabular}{|c|c|c|}
\hline Rentang & Frequensi & Persentase (\%) \\
\hline $22-25$ & 1 & 0.3 \\
$26-29$ & 11 & 3 \\
$30-33$ & 58 & 15.8 \\
$34-37$ & 94 & 25.6 \\
$38-41$ & 80 & 21.8 \\
$42-45$ & 63 & 17.2 \\
$46-49$ & 36 & 9.8 \\
$50-53$ & 15 & 4.1 \\
$54-57$ & 7 & 1.9 \\
$58-61$ & 2 & 0.5 \\
Total & $\mathbf{3 6 7}$ & $\mathbf{1 0 0 . 0}$ \\
\hline
\end{tabular}

Sumber: Olah data menggunakan SPSS versi 22

Tabel di atas menunjukan bahwa rentang 22-25 sebanyak 1 (0,3\%), rentang 26-29 sebanyak 11 (3\%), rentang 30-33 sebanyak 58 (15,8\%), rentang 34-37 sebanyak 94 (25,6\%), rentang 38-41 sebanyak 80 (21,8\%), rentang 42-45 sebanyak 62 (17,2\%), rentang 46-49 sebanyak $36(9,8 \%)$, rentang 50-53 sebanyak $15(4,1 \%)$, rentang 54-57 sebanyak $7(1,9 \%)$ dan rentang 58-61 sebanyak $2(0,5 \%)$.

d. Nilai Mata Pelajaran Pendidikan Kewarganegaraan (PKn)

Berdasarakan analisis data dengan menggunakan bantuan pogram SPSS variabel terikat (dependen) atau variabel $\mathrm{Y}$ tegasnya prestasi belajar Pendidikan Kewarganegaraan (PKn) diperoleh hasil mean sebesar 82,22 standar deviasi sebesar 3,875. Skor terrendah responden adalah 75 dan skor tertinggi adalah 94 .

Agar lebih mudah dipahami dan supaya lebih mudah dibaca, maka data tersebut peneliti tampilkan dalam bentuk tabel sebagaimana tertera pada tabel berikut ini:

\section{Tabel 4 Distribusi Fekuensi Bergolong Prestasi Belajar Pendidikan Kewarganegaraan}

\begin{tabular}{|c|c|c|}
\hline Rentang & Frequensi & Persentase (\%) \\
\hline $75-76$ & 24 & 6.5 \\
$77-78$ & 50 & 13.6 \\
$79-80$ & 63 & 17.2 \\
$81-82$ & 63 & 17.2 \\
$83-84$ & 55 & 15.0 \\
$85-86$ & 62 & 16.9 \\
$87-88$ & 26 & 7.1 \\
$89-90$ & 21 & 5.7 \\
$91-92$ & 2 & 0.5 \\
$93-94$ & 1 & 0.3 \\
Total & $\mathbf{3 6 7}$ & $\mathbf{1 0 0 . 0}$ \\
\hline
\end{tabular}

Sumber: Olah data menggunakan SPSS versi 22 
Dari tabel di atas dinyatakan bahwa rentang 75-76 sebanyak 24 (6,5\%), rentang 77-78 sebanyak $50(13,6 \%)$, rentang 79-80 sebanyak 63 (17,2\%), rentang 81-82 sebanyak 63 (17,2\%), rentang 83-84 sebanyak 55 (15\%), rentang 85-86 sebanyak 62 (16,9\%), rentang 87-88 sebanyak $26(7,1 \%)$, rentang 89-90 sebanyak $21(5,7 \%)$, rentang 91-92 sebanyak $2(0,5 \%)$ dan rentang 9394 sebanyak $1(0,3 \%)$.

\section{B. Analisis Data dan Pengujian Hipotesis}

Sebelum mengajukan hipotesi dalam penelitian ini, peneliti dengan sengaja melakukan analisis data, karena faktanya data yang sudah terkumpul harus dianalisis kembali, supaya data yang disajikan nantinya bisa sesuai dengan harapan peneliti itu sendiri.

\section{Analisis data}

Sebelum data dianalisis, terlebih dahulu dilakukan uji persyaratan analisis. Hal ini perlu untuk dilakukan supaya hasil analisis lebih akurat. Uji persyaratan analisis meliputi lima hal, antara lain: uji normalitas, uji linieritas, uji Multikolinearitas, uji heteroskedastisitas dan autokorelasi. Kelima uji persyaratan analisis tersebut dilakukan dengan bantuan komputer melalui program SPSS versi 22 for windows. Berikut ini adalah hasil persyaratan analisis:

\section{a. Uji Normalitas}

Uji normalitas dimaksudkan untuk mengetahui apakah distribusi frekuensi dari gejala yang diselidiki benar-benar menyimpang secara signifikan dari frekuensi harapan dalam distribusi normal. Data dari keempat variabel dalam penelitian ini diuji normalitasnya dengan menggunakan Kolmogorov Smirnov. Hasil uji normalitas dapat dilihat pada tabel di bawah ini:

Tabel 5 Hasil uji normalitas One-Sample Kolmogorov-Smirnov Test

\begin{tabular}{|ll|r|}
\hline & & $\begin{array}{r}\text { Unstandardize } \\
\text { d Residual }\end{array}$ \\
\hline N & & 367 \\
Normal Parameters & Mean & .0000000 \\
Most Extreme & Std. Deviation & 3.75932654 \\
Differences & Absolute & .032 \\
Kolmogorov-Smirnov Z & .032 \\
Asymp. Sig. (2-tailed) & Positive & -.029 \\
\hline
\end{tabular}

a. Test distribution is Normal.

b. Calculated from data.

Sumber: Olah data menggunakan SPSS versi 22 
Berdasarkan tabel 5 di atas dapat diketahui bahwa nilai Asymp. Sig. sebesar $0.859>0,05$, sehingga dapat ditarik kesimpulan bahwa data berdistribusi normal.

\section{b. Uji Linieritas}

Uji liniritas dimaksudkan untuk mengetahui adanya hubungan yang linier/ sejalan atau tidak setiap variabel bebas $(\mathrm{X})$ terhadap variabel terikat $(\mathrm{Y})$. Oleh karena itu uji linieritas dalam penelitian ini mencakup tiga hal, yaitu linieritas kecerdasan intelektual (X1) terhadap prestasi belajar Pendidikan Kewarganegaraan (Y), linieritas kecerdasan emosional (X2) terhadap prestasi belajar Pendidikan Kewarganegaraan (Y), dan linieritas kecerdasan spiritual (X3) terhadap prestasi belajar Pendidikan Kewarganegaraan (Y). Hasil uji dari setiap hubungan tersebut peneliti uraikan seperti di bawah ini:

\section{1) Pengaruh Kecerdasan Intelektual Terhadap Prestasi Belajar PKn}

Dari hasil analisis data dengan menggunakan batuan komputer melalui program SPSS versi 22 for windows diketahui linieritas kecerdasan intelektual terhadap prestasi belajar pendidikan kewarganegaraan. Dengan sengaja peneliti menyajikan 2 cara untuk menentukan linieritas yaitu dengan melihat angka yang terdapat pada Deviation from Linearity. Cara yang pertama peneliti mengajak dengan melihat angka signifikansi yang terdapat pada olah data (output data) dari SPSS, dan yang kedua dengan membandingkan antara nilai $\mathrm{F}_{\text {hiung }}$ dengan $\mathrm{F}_{\text {tabel }}$. Hasil uji linieritas dapat dilihat pada tabel 6 di bawah ini:

Tabel 6 Hasil uji linieritas X1

ANOVA Table

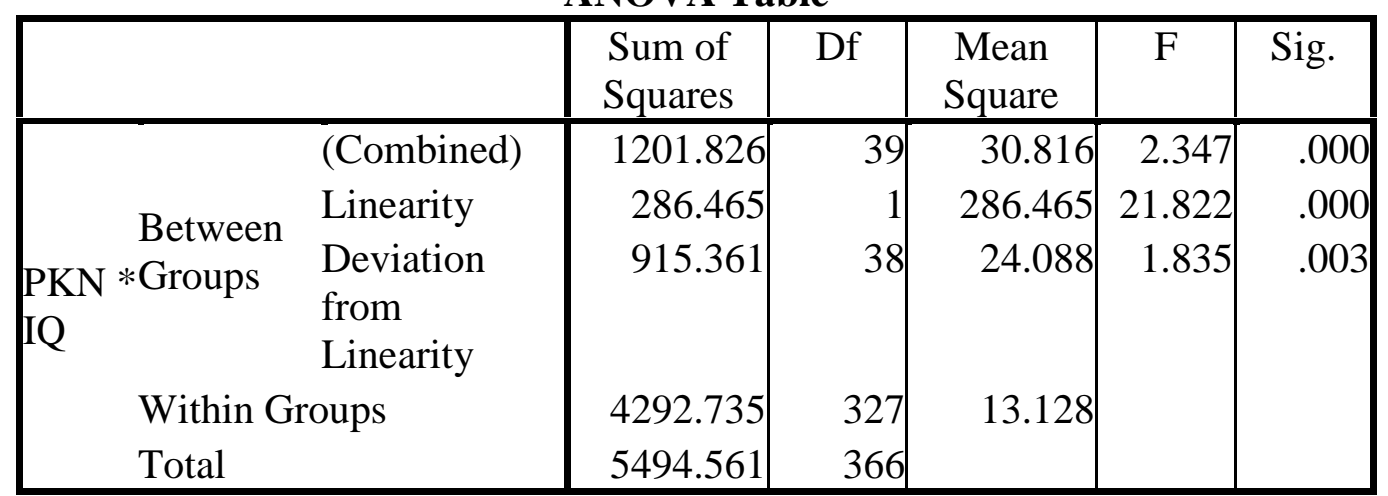

Sumber: Olah data menggunakan SPSS versi 22

Yang pertama dengan melihat nilai signifikansi, dengan ketentuan: Jika nilai Sig. deviation from linearity > 0,05, maka terdapat hubungan yang linier antara variabel bebas dengan variabel terikat. Dan Jika nilai Sig. deviation from linearity $<0,05$, maka tidak terdapat hubungan yang linier antara variabel bebas dengan variabel terikat (hasil olah data terlampir). 
Berdasarkan hasil uji linieritas diketahui nilai Sig. deviation from linierity sebesar 0,03 <0,05, maka dapat disimpulkan bahwa tidak terdapat hubungan yang linier antara tingkat kecerdasan intelektuan terhadap prestasi belajar Pendidikan Kewarganegaraan.

Yang kedua dengan membandingkan antara $\mathrm{F}_{\text {hitung }}$ dengan $\mathrm{F}_{\text {tabel }}$, dengan ketentuan: Jika nilai $F_{\text {hitung }}<\mathrm{F}_{\text {tabel }}$, maka terdapat hubungan yang linier antara variabel bebas dengan variabel terikat. Jika nilai $F_{\text {hitung }}>F_{\text {tabel}}$, maka tidak terdapat hubungan yang linier antara variabel bebas dengan varibel terikat (tabel perhitungan terlampir). Berdasarkan olah data dengan menggunakan SPSS, diketahui nilai $F_{\text {hitung }} 7,312>F_{\text {tabel }} 1,835$ sehingga dapat disimpulkan bahwa tidak terdapat hubungan yang linier antara kecerdasan intelektual terhadap prestasi belajar Pendidikan Kewarganegaraan.

\section{2) Pengaruh Kecerdasan Emosional Terhadap Prestasi Belajar PKn}

Pertama dengan melihat nilai signifikansi, dengan ketentuan: Jika nilai Sig. deviation from linearity $>0,05$, maka terdapat hubungan yang linier antara variabel bebas dengan variabel terikat. Dan Jika nilai Sig. deviation from linearity $<0,05$, maka tidak terdapat hubungan yang linier antara variabel bebas dengan variabel terikat (hasil olah data terlampir). Berdasarkan hasil uji linieritas diketahui nilai Sig. deviation from linierity sebesar 0,114 >0,05, maka dapat disimpulkan bahwa terdapat hubungan yang linier antara kecerdasan emosional terhadap prestasi belajar Pendidikan Kewarganegaraan.

Kedua dengan membandingkan antara $\mathrm{F}_{\text {hitung }}$ dengan $\mathrm{F}_{\text {tabel }}$, dengan ketentuan: Jika nilai $F_{\text {hitung }}<F_{\text {tabel}}$, maka terdapat hubungan yang linier antara variabel bebas dengan variabel terikat. Jika nilai $F_{\text {hitung }}>F_{\text {tabel}}$, maka tidak terdapat hubungan yang linier antara variabel bebas dengan varibel terikat (tabel perhitungan terlampir). Berdasarkan olah data dengan menggunakan SPSS,

diketahui nilai $\mathrm{F}_{\text {hitung }} 1,314<\mathrm{F}_{\text {tabel }} 1,48$, sehingga dapat disimpulkan bahwa terdapat hubungan yang linier antara kecerdasan emosional terhadap prestasi belajar Pendidikan Kewarganegaraan. Hasil uji linieritas dapat dilihat pada tabel 7 di bawah ini: 
Tabel 7 Hasil uji linieritas X2

ANOVA Table

\begin{tabular}{|c|c|c|c|c|c|c|}
\hline & $\begin{array}{l}\text { Sum of } \\
\text { Squares }\end{array}$ & $\mathrm{df}$ & $\begin{array}{l}\text { Mean } \\
\text { Square }\end{array}$ & $\mathrm{F}$ & Sig. \\
\hline \multirow{4}{*}{$\begin{array}{l}\text { Between } \\
\text { PKN } * \text { Groups } \\
\text { EQ }\end{array}$} & (Combined) & 722.376 & 37 & 19.524 & \multirow{6}{*}{$\begin{array}{l}1.346 \\
2.507 \\
1.314\end{array}$} & \multirow{6}{*}{$\begin{array}{l}.093 \\
.114 \\
.114\end{array}$} \\
\hline & Linearity & 36.370 & 1 & 36.370 & & \\
\hline & Deviation & 686.007 & 36 & 19.056 & & \\
\hline & $\begin{array}{l}\text { from } \\
\text { Linearity }\end{array}$ & & & & & \\
\hline \multirow{2}{*}{\multicolumn{2}{|c|}{$\begin{array}{l}\text { Within Groups } \\
\text { Total }\end{array}$}} & 4772.185 & 329 & \multirow[t]{2}{*}{14.505} & & \\
\hline & & 5494.561 & 366 & & & \\
\hline
\end{tabular}

Sumber: Olah data menggunakan SPSS versi 22

\section{3) Pengaruh Kecerdasan Spiritual Terhadap Prestasi Belajar PKn}

Dari hasil analisis data dengan menggunakan batuan komputer melalui program SPSS versi 22 diketahui linieritas kecerdasan Spiritual terhadap prestasi belajar pendidikan kewarganegaraan. Dengan sengaja peneliti menyajikan 2 cara untuk menentukan linieritas yaitu dengan melihat angka yang terdapat pada Deviation from Linearity. Cara yang pertama peneliti mengajak dengan melihat angka signifikansi yang terdapat pada olah data (output data) dari SPSS, dan yang kedua dengan membandingkan antara nilai $\mathrm{F}_{\text {hiung }}$ dengan $\mathrm{F}_{\text {tabel. }}$. Hasil uji linieritas dapat dilihat pada tabel 8 di bawah ini:

Tabel 8 Hasil uji linieritas X3

ANOVA Table

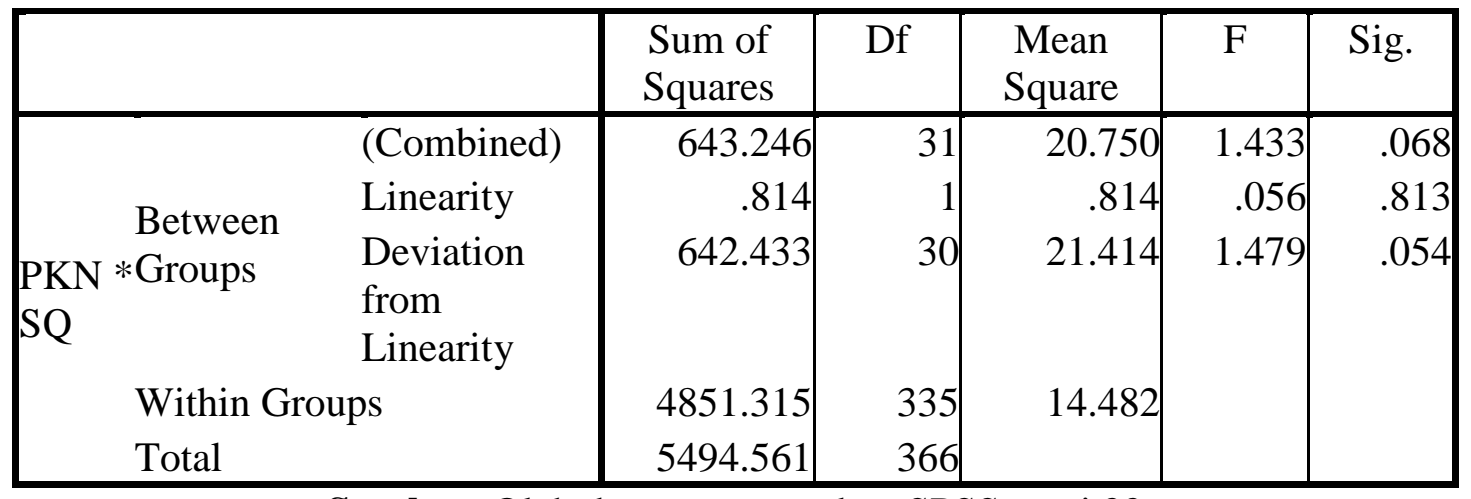

Sumber: Olah data menggunakan SPSS versi 22

Yang pertama dengan melihat nilai signifikansi, dengan ketentuan: Jika nilai Sig. deviation from linearity > 0,05 maka terdapat hubungan yang linier antara variabel bebas dengan variabel terikat. Dan Jika nilai Sig. deviation from linearity $<0,05$ maka tidak terdapat hubungan yang linier antara variabel bebas dengan variabel terikat (hasil olah data terlampir). Berdasarkan hasil uji linieritas diketahui nilai Sig. deviation from linierity sebesar 0,054>0,05 maka dapat 
disimpulkan bahwa terdapat hubungan yang linier antara kecerdasan spiritual terhadap prestasi belajar Pendidikan Kewarganegaraan.

Yang kedua dengan membandingkan antara $F_{\text {hitung }}$ dengan $F_{\text {tabel }}$, dengan ketentuan: Jika nilai $F_{\text {hitung }}<\mathrm{F}_{\text {tabel}}$, maka terdapat hubungan yang linier antara variabel bebas dengan variabel terikat. Jika nilai $F_{\text {hitung }}>F_{\text {tabel, }}$, maka tidak terdapat hubungan yang linier antara variabel bebas dengan varibel terikat (tabel perhitungan terlampir). Berdasarkan olah data dengan menggunakan SPSS, diketahui nilai $F_{\text {hitung }} 1,479<\mathrm{F}_{\text {tabel }}$ 1,52 sehingga dapat disimpulkan bahwa terdapat hubungan yang linier antara kecerdasan spiritual terhadap prestasi belajar Pendidikan Kewarganegaraan.

\section{c. Uji Multikolinearitas}

Dari hasil analisis data dengan menggunakan batuan komputer melalui program SPSS versi 22 for windows diketahui Multikolinearitas kecerdasan intelektual (X1), kecerdasan emosional (X2), kecerdasan spiritual (X3). Uji Multikolinearitas bertujuan untuk menguji apakah dalam model regresi ditemukan adanya korelasi antar variabel bebas. Dikarenakan model regresi yang baik seharusnya tidak terjadi korelasi diantara variabel bebas.

Dengan sengaja peneliti menyajikan 2 cara untuk menentukan Multikolinearitas. Dasar pengambilan keputusannya pun ada dua cara, yang pertama berdasarkan nilai tolerance (T), dan yang kedua berdasarkan nilai Variance Inflation Factor (VIF). Menurut Hair dkk, dalam Hengky Lata dan Salva Temalagi (2013: 63) nilai yang direkomendasikan untuk menunjukan tidak adanya problem Multikolinearitas adalah nilai tolerance $(\mathrm{T})$ harus $>0,10$ dan nilai VIF < 10,0. Hasil uji multikolinearitas dapat dilihat pada tabel berikut:

Tabel 9 Hasil uji multikolinearitas

\begin{tabular}{|c|c|c|}
\hline \multirow{2}{*}{ Model } & \multicolumn{2}{|c|}{ Collinearity Statistics } \\
\cline { 2 - 3 } & Tolerance & VIF \\
\hline (Constant) & & \\
IQ & .991 & 1.009 \\
EQ & .524 & 1.909 \\
SQ & .526 & 1.901 \\
\hline
\end{tabular}

Sumber: Olah data menggunakan SPSS versi 22

Dua hal yang dimaksud adalah pertama pengambilan keputsannya berdasarkan nilai tolerance, dengan ketentuan: jika nilai tolerance > 0,10 maka dapat disimpulkan tidak terjadi Multikolinearitas antar variabel. Sebaliknya jika nilai tolerance $<0,10$ maka dapat disimpulkan 
terjadi Multikolinearitas antar variabel. Berdasarkan tabel 23 di atas yang merupakan output data dengan menggunakan bantuan komputer melaui program SPSS versi 22 for windows bahwa nilai tolerance X1 sebesar 0,991, X2 sebesar 0,524 dan X3 sebesar 0,526 maka dapat disimpulkan bahwa X1, X2 dan X3 tidak terjadi multikolinearitas dikarenakan nilai tolerancy > 0,10 tegasnya dapat disimpulkan bahwa antar variabel bebas tidak terjadi multikolinearitas atau tidak terjadi problem multikolinearitas, dengan kata lain tidak terjadi hubungan antar variabel bebas tersebut (hasil output data sebagaimana terlampir).

Yang kedua pengambilan keputusan berdasarkan nilai VIF, dengan ketentuan: Jika nilai VIF < 10 maka dapat disimpulkan bahwa tidak terjadi multikolinearitas antar variabel. Dan apabila sebaliknya jika nilai VIF > 10 maka dapat disimpulkan bahwa terjadi multikolinearitas antar variabel. Berdasarkan tabel 20 di atas yang merupakan output data dengan menggunakan bantuan komputer melaui program SPSS versi 22 for windows bahwa nilai VIF X1 sebesar 1,009, X2 sebesar 1,909 dan X3 sebesar 1,901 maka dapat disimpulkan bahwa X1, X2 dan X3 tidak terjadi multikolinearitas dikarenakan nilai VIF $<10,00$ (hasil output data sebagaimana terlampir).

\section{d. Heteroskedastisitas}

Dari hasil analisis data diketahui heteroskedastisitas kecerdasan intelektual (X1), kecerdasan emosional (X2), kecerdasan spiritual (X3. Uji heteroskedastisitas bertujuan untuk menguji apakah dalam model regresi terjadi ketidaksamaan variance dari residual satu pengamatan ke pengamatan yang lain, dikarenakan asumsi yang baik dalam model regresi adalah tidak terjadinya masalah heteroskedastisitas. Hasil uji heteroskedastisitas dapat dilihat pada tabel 10 berikut ini:

Tabel 10 Hasil uji heteroskedastisitas Coefficients $^{\mathrm{a}}$

\begin{tabular}{|c|c|c|c|c|c|}
\hline \multirow[t]{2}{*}{ Model } & \multicolumn{2}{|c|}{$\begin{array}{c}\text { Unstandardized } \\
\text { Coefficients }\end{array}$} & $\begin{array}{l}\text { Standardized } \\
\text { Coefficients }\end{array}$ & \multirow[t]{2}{*}{$\mathrm{t}$} & \multirow[t]{2}{*}{ Sig. } \\
\hline & B & Std. Error & Beta & & \\
\hline \multirow{4}{*}{$\begin{array}{l}\text { (Constant) } \\
\text { IQ } \\
\text { EQ } \\
\text { SQ }\end{array}$} & 1.862 & 2.161 & & .862 & .389 \\
\hline & .017 & .016 & .058 & 1.099 & .273 \\
\hline & -.042 & .023 & -.128 & -1.783 & .075 \\
\hline & .032 & .025 & .091 & 1.263 & .207 \\
\hline
\end{tabular}

a. Dependent Variable: ABS_RES

Sumber: Olah data menggunakan SPSS versi 22 
Dasar pengambilan keputusannya adalah: Jika nilai Sig. > 0,05 maka dapat disimpulkan tidak terjadi heteroskedastisitas. Dan apabila sebaliknya jika nilai Sig. $<0,05$ maka dapat disimpulkan terjadi heteroskedastisitas. Berdasarkan pada tabel 24 di atas dapat diketahui bahwa nilai Sig. X1 sebesar 0,273, X2 sebesar 0,075 dan X3 sebesar 0,207 maka dapat disimpulkan bahwa X1, X2 dan X3 tidak terjadi heteroskedastisitas dikarenakan nilai Sig. > 0,05 (hasil output data sebagaimana terlampir).

\section{e. Autokorelasi}

Uji autokorelasi adalah untuk menguji apakah dalam metode regresi linier terdapat korelasi antara kesalahan pengganggu (disturbance) pada periode $\mathrm{t}$ dengan kesalahan pada periode t1 (sebelumnya). Untuk mendiagnosis adanya autokorelasi dalam suatu model regresi dilakukan melalui pengujian terhadap nilai uji durbin-watson. Dasar pengambilan keptusan ada tidaknya autokorelasi sebagai berikut: 1. Apabila DW < DWl atau DW > 4-DWl, maka koefisien autokorelasi $>0$. maka dapat disimpulkan terdapat autokrelasi. 2. Apabila DW $<$ DWl $<4-D W u$, maka koefisiensi autokorelasi $=0$, berarti dapat disimpulkan tidak terdapat autokorelasi. 3 . Apabila DWl < DW < DWu atau 4-DWu < DW < 4-DWu, maka hasilnya tidak dapat disimpulkan. Hasil uji autokorelasi dapat dilihat pada tabel 11 di bawah ini:

Tabel 11 Hasil uji autokorelasi

\begin{tabular}{|c|c|c|c|c|}
\hline DW & DWl & Dwu & 4-DWl & 4-Dwu \\
\hline 1,076 & 1.81591 & 1.83825 & 2.18409 & 2.16175 \\
\hline
\end{tabular}

Sumber: Olah output data SPSS dan tabel durbin watson

Berdasarkan tabel 11 di atas dan dengan melihat tabel durbin watson dapat ditarik kesimpulan bahwa nilai DW sebesar 1,076, DWl sebesar 1.81591 dan nilai 4-DWu sebesar 2.16175 maka sama dengan ketentuan yang ke 2, dimana DW < DWl < 4-DWu, maka jelas dapat disimpulkan bahwa tidak terdapat autokorelasi.

\section{PEMBAHASAN HASIL PENELITIAN}

1. Pengaruh kecerdasan intelektual terhadap prestasi belajar PKn

Analisis yang dilakukan dalam penelitian ini menggunakan bantuan komputer melalui program SPSS versi 22 for windows hasil analisis menunjukan bahwa pengaruh kecerdasan intelektual terhadap prestasi belajar pada taraf signifikansi 5\% nilai sig. $0,00<$ nilai sig. 0,05 yang berarati terdapat pengaruh positif yang signifikan kecerdasan intelektual terhadap prestasi belajar Pendidikan Kewarganegaraan. Persamaan regresi juga menunjukan variabel bebas kecerdasan intelektual $\left(\mathrm{X}_{1}\right)$, bertanda positif yang berarti berpengaruh positif terhadap variabel 
prestasi belajar PKn (Y). Sehingga dapat dinyatakan terdapat pengaruh positif yang signifikan kecerdasan intelektual terhadap prestasi belajar PKn.

Hasil penelitian ini membuktikan bahwa kecerdasan intelektual berpengaruh terhadap tinggi rendahnya prestasi belajar PKn tersebut. Ini dapat diartikan siswa yang memiliki kecerdasan intelektual yang tinggi maka secara serta merta prestasi belajar PKn-nya tinggi. Demikian pula sebaliknya siswa yang memiliki kecerdasan intelektual rendah maka cenderung rendah pula nilai prestasi belajar PKn-nya. Kecerdasan intelektual merupakan hal yang paling dominan dalam meningkatkan prestasi belajar siswa, maka dari itu peneliti sepakat dengan program pendidikan yang berpusat pada kecerdasan intelektual. Biasanya tolok ukur kecerdasan intelektual adalah dari tes IQ dengan skor tinggi, nilai rapor yang baik, indek prestasi yang tinggi dan bahkan bisa juga yang sering menjadi juara kelas. Akan tetapi peneliti juga menyadari kecerdasan intelektual bukan satu-satunya faktor, dalam artian terdapat faktor lain yang juga sama-sama penting yaitu kecerdasan emosional dan kecerdasan spiritual. Karena peneliti meyakini apabila hanya kecerdasan intelektual saja tidak cukup atau hanya berorientasi untuk mengahsilkan nilai akademik yang baik saja tidak cukup, karena yang diperlukan adalah bagaimana mengembangkan kecerdasan hati, mampu mengelola perasaan, seperti pengenalan diri, pengendalian diri dan kemampuan untuk memotivasi diri sendiri, bahkan kesanggupan seseorang dalam mengahadapi frustasi, kesanggupan mengendalikan dorongan dan menunda kepuasan sesaat, mengartur suasana hati yang reaktif serta mampu berempati dan bekerja sama dengan orang lain, itulah pentingnya kecerdasan emosional. Tidak hanya kecerdasan intelektual dan kecerdasan emosional saja, ada satu hal lagi yang tidak kalah penting yaitu kecerdasan spiritual. Karena spiritual siswa yang cerdas akan mampu membantu dalam memecahkan permasalahan-permasalahan yang dihadapinya, karena apabila hanya berpusat pada kecerdasan intelektual tanpa menyeimbangkan sisi spiritual maka akan menghasilkan generasi yang mudah putus as, depresi, suka tawuran bahkan menggunakan obat-obatan terlarang, begitu pula dalam hal belajar, seorang siswa yang hanya mengejar prestasi belajar berupa nilai dan mengabaikan nilai spiritual, maka kelak akan mengahalkan segala cara untuk mendapatkan nilai yang bagus, dan mereka cenderung untuk bersikap tidak jujur seperti mencontek pada saat ujian. Pentingnya kecerdasan spiritual karena mampu mendorong berfungsinya secara efektif kecerdasan intelektual dan kecerdasan emosional. 
2. Pengaruh kecerdasan emosional terhadap prestasi belajar PKn

Hasil analisis menunjukan bahwa pengaruh kecerdasan emosional terhadap prestasi belajar pada taraf signifikansi 5\% dengan nilai sig. (P) 0,119> nilai sig. (P) 0,05 yang berarati terdapat pengaruh positif tidak signifikan kecerdasan emosional terhadap prestasi belajar mata pelajaran PKn.

Persamaan regresi juga menunjukan variabel bebas kecerdasan emosional $\left(\mathrm{X}_{2}\right)$, bertanda negatif yang berarti tidak berpengaruh positif terhadap variabel prestasi belajar PKn (Y). Selanjutnya pada taraf signifikansi $5 \%$ yang dipersyaratkan sig. $(\mathrm{P})<0,05$, akan tetapi nilai sig. (P) adalah 0,119 melebihi yang disyaratkan oleh tingkat signifikansi 5\%. Ini berarti tidak memenuhi persyaratan kesignifikanan, sehingga dapat penleiti simpulkan kecerdasan emosional tidak memiliki pengaruh positif yang signifikan terhadap prestasi belajar PKn.

Besarnya persamaan regresi variabel kedua tersebut juga kecil dan juga bertanda negatif yaitu -0,064. Dari analisis ini dapat dapat peneliti simpulkan apabila kecerdasan emosional meningkat $1 \%$ maka akan berakibat naiknya prestasi belajar PKn siswa tersebut sebesar $-0,064$ $\%$. Persentase ini juga menunjukan kecilnya nilai korelasi, selain kecil juga bertanda negatif pula kecerdasan emosional terhadap prestasi belajar PKn.

Hasil penelitian menegaskan bahwa prestasi belajar PKn siswa tidak dipengaruhi oleh kecerdasan emosional siswa tersebut. Ini dapat pula diartikan siswa yang memiliki kecerdasan emosional yang tinggi tidak serta merta prestasi belajar PKn-nya tinggi, demikian pula sebaliknya. Kecilnya pengaruh kecerdasan emosional terhadap prestasi belajar PKn siswa sangat mungkin teorinya sudah berubah. Artinya dalam pembelajaran PKn tidak ditentukan oleh kecerdasan emosional tetapi lebih dipengaruhi oleh faktor lain.

3. Pengaruh kecerdasan spiritual terhadap prestasi belajar PKn

Hasil analisis menunjukan bahwa pengaruh kecerdasan spiritual terhadap prestasi belajar PKn menunjukan pada taraf signifikansi 5\% dengan nilai sig. (P) 0,365>0,05 yang berarati terdapat pengaruh positif yang tidak signifikan kecerdasan spiritual terhadap prestasi belajar mata pelajaran PKn. Persamaan regresi juga menunjukan kecerdasan spiritual $\left(\mathrm{X}_{3}\right)$, bertanda positif yang berarti berpengaruh positif terhadap prestasi belajar PKn (Y). Persamaan regresi sebesar 0, 040, meskipun angkanya kecil akan tetapi tetap berpengaruh positif tapi tidak signifikan. 
Hasil penelitian menunjukan bahwa kecerdasan spiritual berpengaruh terhadap tinggi rendahnya prestasi belajar PKn siswa tersebut. Maka apabila seorang siswa memiliki kecerdasan spiritual yang tinggi maka prestasi belajar PKn-nya akan tinggi. Demikian pula sebaliknya siswa yang kecerdasan spiritualnya rendah maka cenderung rendah pula prestasi belajar PKn-nya.

4. Pengaruh kecerdasan intelektual, emosional dan spiritual secara simultan terhadap prestasi belajar PKn

Analisis yang dilakukan dengan bantuan komputer dengan program SPSS versi 22 for windows tepatnya, didapatkan $\mathrm{F}_{\text {hitung }}$ sebesar 7,534 $>\mathrm{F}_{\text {tabel }} 2.629231276$ untuk taraf signifikansi $5 \%$ sig. $(\mathrm{P})$ sebesar 0,000 . Nilai $\mathrm{P} 0,000<0,05$ berarti terdapat pengaruh positif yang signifikan ketiga variabel bebas $\left(\mathrm{X}_{1}, \mathrm{X}_{2}\right.$ dan $\left.\mathrm{X}_{3}\right)$ secara simultan terhadap variabel terikat $(\mathrm{Y})$. Ini sebagai petunjuk bahwa kecerdasan intelektual, kecerdasan emosional dan kecerdasan spiritual secara simultan mempengaruhi tinggi rendahnya prestasi belajar Pendidikan Kewarganegaraa siswa.

\section{PENUTUP}

\section{A. Simpulan}

Berdasarkan hasil penelitian dan pembahasan yang telah dipaparkan oleh peneliti pada bab sebelumnya, maka dapatlah diambil simpulan sebagai berikut:

1. Terdapat pengaruh positif yang signifikan kecerdasan intelektual terhadap prestasi belajar PKn. Semakin tinggi kecerdasan intelektual siswa maka semakin tinggi pula prestasi belajar PKn yang dicapainya.

2. Terdapat pengaruh positif yang tidak signifikan kecerdasan emosional terhadap prestasi belajar PKn. Artinya baik buruknya prestasi belajar mata pelajaran PKn siswa tidak dipengaruhi oleh kecerdasan emosionalnya.

3. Terdapat pengaruh positif yang tidak signifikan kecerdasan spiritual terhadap prestasi belajar PKn. Maka apabila seorang siswa memiliki kecerdasan spiritual yang tinggi tidak serta merta prestasi belajar PKn-nya akan tinggi.

4. Terdapat pengaruh yang positif dan signifikan kecerdasan intelektual, emosional dan spiritual secara simultan terhadap prestasi belajar PKn. Semakin tinggi kecerdasan intelektual, emosional dan spiritual maka akan membawa pengaruh pada tingginya prestasi belajar PKn yang diraih siswa. 


\section{B. Saran}

Berdasarkan penelitian, pembahasan dan simpulan yang dihasilkan, agar prestasi belajar mata pelajaran PKn siswa SMA Negeri se-Kota Yoyakarta dapat optimal maka kepada guru, siswa dan sekolah dapatlah diajukan saran-saran sebagai berikut:

1. Bagi Guru

Guru-guru SMA Negeri se-Kota Yogyakarta dalam melakukan kegiatan belajar mengajar (KBM) mata pelajaran Pendidikan Kewarganegaraan (PKn) diharapkan dapat meningkatkan kecerdasan intelektial siswa diantaranya dengan memberikan kuis yang secara serentak dan tibatiba serta harus dijawab oleh siswa dengan cepat dan tepat tanpa harus membuka buku lembar kerja siswa (LKS) atau buku paket yang dimiliki oleh maisng-maisng siswa. Supaya para siswa terbiasa berpikir cepat dan tanggap situasi yang pada akhirnya bisa meningkatkan kualitas kecerdasan intelektual siswa itu sendiri.

Didalam melaksanakan kegiatan pembelajaran mata pelajaran PKn, guru-guru SMA Negeri se-Kota Yogyakarta juga diharapkan tidak terlalu memfokuskan pada kecerdasan emosional siswa saja. Peneliti menyadari apabila siswa yang hanya memiliki kecerdasan intelektual tanpa diimbangi oleh kecerdasan emosional sangatlah tidak baik, apabila terjadi seperti itu dikhawatirkan akan terjadi kurangnya mengelola perasaan, kurangnya memotivasi diri sendiri, bahkan ketidak tegaran ketika menghadapi masalah yang pada akhirnya akan mengalami frustasi.

Selanjutnya, guru-guru SMA Negeri se-Kota Yogyakarta pula diharapkan untuk tidak memfokuskan hanya kepada kecerdasan spiritual saja, meskipun peneliti menyadari apabila siswa yang hanya memiliki kecerdasan intelektual tanpa diimbangi oleh kecerdasan emosional sangatlah tidak baik, peneliti mengkhawatirkan akan terlahirnya generasi muda yang mudah putus asa, depresi, suka tawuran dan bahkan mengkonsumsi obat-obatan terlarang, yang paling dikhawatirkan adalah menghalalkan segala cara untuk mendapatkan nilai yang bagus, dan pada akhirnya cenderung untuk bersikap tidak jujur seperti menyontek pada saat ujian.

2. Bagi Siawa

Bagi para siswa SMA Negeri se-Kota Yogyakarta diharapkan dalam mengikuti pembelajaran $\mathrm{PKn}$, senantiasa untuk selalu mengedepankan kecerdasan intelektual dan diimbangi oleh kecerdasan emosional serta diimbangi pula oleh kecerdasan spiritual. Supaya 
nantinya para siswa SMA Negeri se-Kota Yogyakarta bisa mendapatkan nilai yang baik, dari hasil yang baik pula.

3. Bagi Sekolah

Dari hasil penelitian ini kepada sekolah di bawah kepemimpinan kepala Sekolah diharapkan dapat meningkatkan kecerdasan intelektual siswa untuk menunjang prestasi belajar mata pelajaran PKn siswanya. Dikarenakan kecerdasan intelektual berpengaruh sangat besar terhadap prestasi belajar mata pelajaran PKn siswa, yang pada gilirannya akan meningkatkan prestasi belajar mata pelajaran PKn siswa SMA Negeri se-Kota Yogyakarta, tanpa mengesampingkan kecerdasan emosional dan kecerdasan spiritual siswa.

\section{DAFTAR PUSTAKA}

Agustian Ary Ginanjar. 2005. Rahasia Sukses Membangun Kecerdasan Emosional dan Spiritual. Jakarta: Penerbit Arga.

Anne Abraham. 2006. "The Need for the Integration of Emotional Intelligence Skills in business education", International Journal University of Wollonggong, Wollonggong: Faculty of Commerce, University of Wollonggong

Aziz Rahmat dan Mangestuti Retno. 2006. "Pengaruh Kecerdasan Intelektual (IQ), Kecerdasan Emosional (EI) dan Kecerdasan Spiritual (SI) Terhadap Agresivitas pada Mahasiswa UIN Malang”, Jurnal: El-Qudwah, Jurnal Penelitian dan Pengembangan, Vol 1, No 1, April 2006, Universitas Islam Negeri Malang.

Danah Zohar dan Ian Marshall. 2007. Kecerdasan Spiritual. Bandung: Penerbit Mizan.

Djasuli M. dan Hidayah Nur. 2013. "Pengaruh Kecerdasan Intelektual, Emosional, dan Spiritual Terhadap Kinerja Variabel Moderasi Kompetensi di Kabupaten Lamongan”, Studi Kasus di SKPD Kabupaten Lamongan, Universitas Trunojoyo Madura.

Emzir, 2010. Metodologi Penelitian Kualitatif Analisis data. Jakarta: Rajawali Press.

Ghozali Imam. 2005. Aplikasi Analisis Multivariate dengan Program SPSS. Semarang: Badan Penerbit Universitas Diponegoro

Hadi Sutrisno. 1993. Metodoligi Research 2. Yogyakarta: Andi Offset.

Hakim Andi. 2013. "Pengaruh Kecerdasan Intelektual, Kecerdasan Emosional, dan kecerdasan Spiritual Terhadap Prestasi Belajar 118 : SMA Negeri di Surakarta Tahun Pelajaran 2012/2013”, Tesis: Fakultas Pascasarjana, Program Studi Pendidikan Ekonomi, Universitas Sebelas Maret Surakarta 
Iqbal Hasan. 2010. Analisis Data Penelitian dengan Statistik. Jakarta: PT Bumi Angkasa.

Nachiappan, dkk. 2013. "Analysis of Cognition Integration in Intelligence Quotient (IQ),

Emotional Quotient (EQ) and Spiritual Quotient (SQ) in Transforming Cameron Highlands

Youths through Hermeneutics Pedagogy”. Disampaikan dalam Konferensi Internasional tentang

Pendidikan \& Psikologi Pendidikan 2013 (ICEEPSY 2013), Sultan Idris Education University,

Tanjung Malim, 35900, Malaysia

Rahmasari Lisda. 2012. "Pengaruh Kecerdasan Intelektual, Kecerdasan Emosional dan

Kecerdasan Spiritual Terhadap Kinerja Karyawan”, Jurnal Fakultas Ekonomi Universitas AKI, Semarang

Sugiyono. 2005. Metode Penelitian Administrasi. Bandung: Penerbit Alfabeta.

Sugiono. 2010. Metodologi Penelitian Pendidikan: Pendekatan Kuantitatif, Kualitatif, dan $R$ \& $D$. Bandung: Alfabeta.

Sugiono. 2011. Metodologi Penelitian Kuantitatif, Kualitatif dan $R \& D$. Bandung: Alfabeta.

Sugiono. 2012. Statistik untuk Penelitian. Bandung: Alfabeta

Tikollah, dkk 2006. "Pengaruh Kecerdasan Intelektual, Kecerdasan Emosional, dan Kecerdasan Spiritual Terhadap Sikap Etis Mahasiswa Akuntansi (Studi Pada Perguruan Tinggi Negeri Di Kota Makassar Provinsi Sulawesi Selatan)”. Padang: Simposium Nasional Akuntansi 9 Jurnal multiparadigma lecture, Universitas Brawijaya

Trihandini, 2005. "Analisis Pengaruh Kecerdasan Intelektual, Kecerdasan Emosi, dan Kecerdasan Spiritual Terhadap Kinerja Karyawan”, Tesis: Fakultas Pascasarjana, Program Studi Magister Manajemen, Universitas Diponegoro, Semarang

Undang-undang Republik Indonesia Nomor 20 Tahun 2003. 2010. Sistem Pendidikan Nasional. Bandung: Citra Umbara. 